\title{
Anterior skull base reconstruction: a contemporary review
}

\author{
Akash N. Naik, Peter J. Lancione, Anuraag S. Parikh, Chen Lin, Dustin A. Silverman, Ricardo L. Carrau, \\ Kyle K. VanKoevering, Nolan B. Seim, Matthew O. Old, Stephen Y. Kang
}

Department of Otolaryngology-Head and Neck Surgery, James Cancer Hospital and Solove Research Institute, The Ohio State University Wexner Medical Center, Columbus, OH 43210, USA.

\begin{abstract}
Correspondence to: Dr. Stephen Y. Kang, Department of Otolaryngology-Head \& Neck Surgery, James Cancer Hospital and Solove Research Institute, The Ohio State University Wexner Medical Center, 460 West 10th Avenue, Columbus, OH 43210, USA. E-mail: Stephen.Kang@osumc.edu
\end{abstract}

\begin{abstract}
How to cite this article: Naik AN, Lancione PJ, Parikh AS, Lin C, Silverman DA, Carrau RL, VanKoevering KK, Seim NB, Old MO, Kang SY. Anterior skull base reconstruction: a contemporary review. Plast Aesthet Res 2021;8:22.
\end{abstract} https://dx.doi.org/10.20517/2347-9264.2021.05

Received: 11 Jan 2021 First Decision: 4 Mar 2021 Revised: 8 Mar 2021 Accepted: 11 Mar 2021 Available online: 8 Apr 2021

Academic Editors: Matthew Spector, Raúl González-García Copy Editor: Yue-Yue Zhang Production Editor: Yue-Yue Zhang

\begin{abstract}
Anterior skull base (ASB) defects present a significant challenge in head and neck reconstructive surgery. The main goal of skull base reconstruction is to create a watertight separation between the intracranial cavity and aerodigestive tract. Successful reconstruction aims to prevent cerebrospinal fluid (CSF) leak, pneumocephalus, and a range of infectious manifestations. Functional outcomes and cosmesis are also critical considerations when developing a reconstructive plan. Advancements with endoscopic endonasal approaches have revolutionized skull base surgery but also have created new reconstructive challenges due to the narrow operative corridor, especially for extensive defects or salvage cases where microvascular free tissue transfer is required. Though a variety of techniques including local, regional, and free flaps have been described, ASB reconstruction remains a difficult undertaking due to the complex anatomy and high risk for post-operative complications. This review provides a comprehensive discussion of available reconstructive techniques that can be used after both open and endoscopic ASB resections to help determine the optimal reconstruction for a variety of defects.
\end{abstract}

Keywords: Anterior skull base, orbitocranial defects, locoregional flaps, free tissue transfer, head and neck reconstruction, skull base surgery 


\section{INTRODUCTION}

Anterior craniofacial defects present significant challenges in head and neck reconstruction ${ }^{[1]}$. Conceptually, the goal of anterior cranial base reconstruction is to separate the cranial cavity from the aerodigestive tract, which demands a watertight closure to prevent cerebrospinal fluid (CSF) leak, pneumocephalus, and meningitis. Soft tissue may also be required to obliterate dead space, provide coverage for critical structures such as the internal carotid artery, and restore optimal function and cosmesis ${ }^{[2,3]}$. Traditional skull base surgery involved open transfacial or transcranial approaches, allowing wide exposure for both tumor excision and reconstruction, albeit with significant associated morbidity. With the advent and evolution of endoscopic skull base surgery, there have been advances in the ablation of complex skull base pathology with minimal access approaches ${ }^{[4]}$. The adoption of endoscopic endonasal skull base surgery has created new challenges for reconstructive surgeons as defects may need to be reconstructed through the narrow sinonasal corridor ${ }^{[5]}$.

Whether an open or endoscopic approach is planned, the method of reconstruction depends on the extent and volume of the defect, presence of CSF leak, need for adjuvant therapy, patient co-morbidities, desired functional/aesthetic outcomes, and available options that may be limited by prior surgery, trauma, or radiation therapy ${ }^{[1,6-8]}$. Among patients with large volume defects, history of radiation treatment, or previously failed reconstruction, local and regional flaps may offer inadequate tissue bulk or vascularity, necessitating microvascular free tissue transfer. Despite the challenging and varied nature of these defects, many reconstructive techniques have been reported ${ }^{[9-12]}$. In particular, open and endoscopic defects often differ greatly in size, location, subsites involved, and accessibility, thus creating a separate set of reconstructive options for these two defect classes. In this article, we comprehensively review a variety of methods and innovative techniques used to reconstruct anterior cranial base and craniofacial defects encountered with both open and endoscopic approaches.

\section{OPEN ANTERIOR SKULL BASE DEFECTS}

Despite a significant shift towards endoscopic skull base surgery, open skull base approaches and reconstruction are still indicated for large skull base defects, extensive craniofacial trauma, osteoradionecrosis, and salvage surgery ${ }^{[6]}[$ Table 1].

\section{Locoregional}

The pericranial or galeopericranial flap has historically been the mainstay option for open anterior skull base (ASB) and craniofacial reconstruction. It is a well vascularized axial flap supplied by the supraorbital and supratrochlear arteries that offers a wide surface area and covers ventral defects extending from the frontal sinus to the planum sphenoidale and sella ${ }^{[4,6,13,14]}$. It has traditionally been harvested via a coronal incision and is comprised of pericranium and subaponeurotic connective tissue ${ }^{[6,14]}$. Others have included the galea to increase the sturdiness and blood supply of the flap. Re-establishment of the dura and skull base integrity are paramount to a successful skull base reconstruction ${ }^{[15]}$. Dural defects are reconstructed with a fascia graft, acellular dermis, pericardium, or cadaveric dura in order to create a watertight closure. The malleable and thin nature of the pericranium is an optimal choice for subsequent skull base reconstruction especially when it is used in conjunction with other soft tissue and bony reconstructions ${ }^{[6,16,17,18]}$. However, it lacks a cutaneous component and the mass needed to reconstruct extensive defects with significant volume loss ${ }^{[19]}$.

The temporoparietal fascia flap, based off the superficial temporal artery, is another excellent reconstructive option but may be better suited for more lateral aspects of the anterior cranial skull base involving the orbit. It is a pliable fascial graft with a long vascular pedicle that can cover a substantial surface area 
Table 1. Reconstructive options for open anterior skull base defects

\begin{tabular}{|c|c|c|c|c|c|}
\hline $\begin{array}{l}\text { Reconstructive } \\
\text { method }\end{array}$ & Clinical indications & Vascular supply & Advantages & Disadvantages & Other considerations \\
\hline \multicolumn{6}{|l|}{ Locoregional flaps } \\
\hline Pericranial & $\begin{array}{l}\text { ASB defects (often used in } \\
\text { combination with other flaps) }\end{array}$ & Supraorbital and supratrochlear a. & $\begin{array}{l}\text {-Thin, malleable flap } \\
\text {-Reliable vascularity } \\
\text {-Extensive surface area }\end{array}$ & $\begin{array}{l}\text {-Lacks tissue volume and skin component } \\
\text {-Alopecia }\end{array}$ & $\begin{array}{l}\text {-Traditionally harvested via } \\
\text { bicoronal incision }\end{array}$ \\
\hline $\begin{array}{l}\text { Temporoparietal } \\
\text { fascia }\end{array}$ & $\begin{array}{l}\text { ASB defects (including lateral } \\
\text { defects extended to orbit) }\end{array}$ & Superficial temporal a. & $\begin{array}{l}\text {-Long vascular pedicle } \\
\text {-Ability to harvest with split calvarial } \\
\text { bone grafts and skin }\end{array}$ & $\begin{array}{l}\text {-Limitations with flap transposition for } \\
\text { midline ASB defects } \\
\text {-Alopecia }\end{array}$ & $\begin{array}{l}\text {-Novel approach via supraorbital } \\
\text { epidural corridor }^{[20]}\end{array}$ \\
\hline Submental flap & $\begin{array}{l}\text { Small volume ASB and orbital } \\
\text { defects }\end{array}$ & Submental a. & $\begin{array}{l}\text {-Thin, pliable tissue with ability to } \\
\text { harvest muscle } \\
\text {-Minimal donor site morbidity } \\
\text {-Cosmetic advantages }\end{array}$ & $\begin{array}{l}\text {-Limited soft tissue volume } \\
\text {-Limited reach with pedicle flap and most } \\
\text { relevant in lateral skull base defects }\end{array}$ & $\begin{array}{l}\text {-Ability to use as hybrid or free } \\
\text { flap }^{[19]}\end{array}$ \\
\hline Temporalis muscle & $\begin{array}{l}\text { Anterolateral defects with } \\
\text { extension to orbit and } \\
\text { infratemporal fossa }\end{array}$ & $\begin{array}{l}\text { Deep temporal branch of internal } \\
\text { maxillary a. }\end{array}$ & $\begin{array}{l}\text {-Minimal donor site morbidity } \\
\text {-Soft tissue component }\end{array}$ & $\begin{array}{l}\text {-Limited reach for anterior/midline } \\
\text { defects } \\
\text {-Temporal wasting } \\
\text {-Trismus }\end{array}$ & \\
\hline $\begin{array}{l}\text { Latissimus dorsi } \\
\text { muscle }\end{array}$ & $\begin{array}{l}\text { Large volume skull base and } \\
\text { orbital defects }\end{array}$ & Thoracodorsal a. & $\begin{array}{l}\text {-Long pedicle and broad arc of rotation } \\
\text {-Ability to harvest skin paddle }\end{array}$ & $\begin{array}{l}\text {-Potential limitations with flap } \\
\text { transposition and ASB coverage } \\
\text {-Excess volume }\end{array}$ & \\
\hline Trapezius muscle & Large volume skull base defects & $\begin{array}{l}\text { Transverse cervical a./dorsal } \\
\text { scapular a. }\end{array}$ & -Thin and pliable myocutaneous flap & -Requires repositioning for harvest & \\
\hline $\begin{array}{l}\text { Pectoralis major } \\
\text { muscle }\end{array}$ & Large volume skull base defects & $\begin{array}{l}\text { Thoracoacromial a. and perforators } \\
\text { arising from internal mammary a. }\end{array}$ & -Minimal donor morbidity & $\begin{array}{l}\text {-Limited reach above the zygomatic arch } \\
\text { for ASB defects }\end{array}$ & \\
\hline \multicolumn{6}{|l|}{ Free flaps } \\
\hline Radial forearm & $\begin{array}{l}\text { Small volume ASB and upper } \\
\text { facial skeleton defects }\end{array}$ & Radial a. & $\begin{array}{l}\text {-Pliable and flexible nature } \\
\text {-Long pedicle length } \\
\text {-Option for osseous component }\end{array}$ & $\begin{array}{l}\text {-Lack of substantial muscle and fat } \\
\text {-Skin graft needed for donor site }\end{array}$ & $\begin{array}{l}\text {-Osseous component useful for } \\
\text { frontal/orbital rim defects }\end{array}$ \\
\hline Rectus abdominis & Large volume skull base defects & Deep inferior epigastric a. & $\begin{array}{l}\text {-Long pedicle length } \\
\text {-Substantial volume and adequate skin } \\
\text { paddle } \\
\text {-Well-compartmentalized fat }\end{array}$ & $\begin{array}{l}\text {-Variable volume due to adipose tissue } \\
\text {-Risk of hernia if anterior rectus sheath } \\
\text { not preserved }\end{array}$ & $\begin{array}{l}\text {-Perforator based-technique can } \\
\text { reduce donor site morbidity }{ }^{[29]}\end{array}$ \\
\hline Anterolateral thigh & Large volume skull base defects & $\begin{array}{l}\text { Descending branch of lateral } \\
\text { circumflex femoral a. }\end{array}$ & $\begin{array}{l}\text {-Perforator based flap } \\
\text {-Option for multiple skin paddles and } \\
\text { substantial volume with vastus lateralis } \\
\text {-Minimal donor site morbidity }\end{array}$ & $\begin{array}{l}\text {-Shorter pedicle compared to rectus or } \\
\text { radial forearm } \\
\text {-Variable volume due to adipose tissue }\end{array}$ & \\
\hline Fibula & $\begin{array}{l}\text { ASB and mid-face }+/ \text { - orbital } \\
\text { defects }\end{array}$ & Peroneal a. & $\begin{array}{l}\text {-Significant bone stock } \\
\text { - Layered fibula great choice for inferior } \\
\text { orbital rim and malar eminence } \\
\text {-Malleable and adequate skin paddle }\end{array}$ & $\begin{array}{l}\text {-Donor site morbidity (need for skin } \\
\text { graft, tendon exposure, decreased ankle } \\
\text { mobility) }\end{array}$ & \\
\hline Latissimus dorsi +/- & Large volume ASB +/- mid-face & Thoracodorsal a. & -Long pedicle length & -Donor site morbidity (decreased & \\
\hline
\end{tabular}


(approximately $14 \mathrm{~cm} \times 17 \mathrm{~cm}$ ) and be harvested with the overlying skin if desired ${ }^{[4,14]}$. It can also be harvested with split calvarial bone grafts to reconstruct high frontal bone defects ${ }^{[12]}$. Ferrari et al ${ }^{[20]}$ proposed a novel approach using a supraorbital epidural corridor through a pterional frontotemporal craniotomy to transpose the flap and help repair ASB defects. The traditional route to transpose the temporoparietal fascia flap is through an infratemporal-transpterygoid tunnel.

The temporalis muscle flap, supplied by the deep temporal branch of the internal maxillary artery, is another option, particularly for immediately adjacent orbital and infratemporal skull base defects. The reach of this flap is limited by its narrow arc of rotation and muscular attachment at the coronoid process ${ }^{[0,21]}$. Chang et al ${ }^{[19]}$ also described the use of the submental flap as an excellent option for ASB, orbital, and high facial defects. In their small case series, there were 5 pedicled, 2 hybridized, and 2 free flap reconstructions with $100 \%$ flap survival ${ }^{[19]}$. Other myocutaneous regional flaps including the latissimus dorsi, trapezius, and pectoralis major have been previously cited for skull base reconstruction ${ }^{[3,22]}$. However, these regional flaps may not be ideal choices for ASB defects due to difficulty in transposing the flap above the inferior orbital rim and zygomatic arch. There may also be limitations with locoregional flaps due to lack of tissue volume, previous interruption of their blood supply, and/or scarring.

\section{Free microvascular tissue transfer}

Free microvascular tissue transfer has emerged in the past 30 years as a reliable reconstructive option for extensive open ASB defects. This approach is beneficial among patients with prior skull base surgery and/or radiation ${ }^{[15]}$, given the independent blood supply from a healthy donor site ${ }^{[2]}$. The vasculature of free tissue transfer can withstand adjuvant radiation therapy and improve healing ${ }^{[15,23]}$. It is also particularly useful for complex orbitofacial defects, as they may require restoration of the bony contour, soft tissue volume of the orbit, and an external skin paddle for facial restoration, in addition to a watertight coverage of the skull base ${ }^{[24-26]}$. Functional and aesthetic outcomes are important considerations, as an extended maxillectomy and orbital exenteration (OE) often involve the hard palate and orbital rim; thus, restoring volume and bony contour with tissue not vulnerable to atrophy is preferred. Meticulous preoperative planning and intraoperative flexibility are important as the expected defect can often change substantially based on intraoperative findings and surgical margins. A multitude of donor sites have been described in the literature including the rectus abdominis ${ }^{[3,21,27-30]}$, anterolateral thigh $(\mathrm{ALT})^{[30-33]}$, radial forearm ${ }^{[2,7]}$, latissimus dorsi and scapula ${ }^{[2,34]}$, fibula ${ }^{[3,35]}$, and omentum ${ }^{[36]}$. The diversity of free flaps provides reconstructive surgeons with an array of options depending on size/volume of defect, location, expected pedicled geometry, and the need for soft tissue and/or bone ${ }^{[2,6]}$.

The rectus abdominis has historically been the workhorse flap for ASB reconstruction ${ }^{[3,9,21,27,28,37]}$. It can be harvested as a myocutaneous or myofascial free flap based off the deep inferior epigastric artery. The rectus abdominis provides substantial muscle volume and well compartmentalized fat to recontour and 
obliterate complex pyramid-shaped defects in addition to an adequate skin paddle for sinonasal lining and external defects ${ }^{[3,6,9,12]}$. In a retrospective review by Chiu et al. ${ }^{[28]}$, the rectus abdominis was used in 68 patients who underwent anterior and middle cranial skull base resection and reconstruction. CSF leak was avoided in $93 \%$ of cases in which the flap was used for reconstruction. Variable subcutaneous tissue volume that is dependent on body habitus and the risk of a ventral hernia are notable disadvantages of this flap ${ }^{[4,9,31]}$. A recent modification of the flap harvest uses a perforator-based technique with three main reconstructive advantages: exceptional pedicle length $(>13 \mathrm{~cm}$ ), highly moldable adipose tissue for flap customization, and the ability to reconstruct closed-space defects due to absence of flap atrophy (insignificant muscular volume $)^{[29]}$. Compared to older methods of harvest that include a large portion of the rectus abdominis muscle, this approach also limits donor site morbidity by preserving the anterior rectus sheath in its entirety. The rectus abdominis continues to be an excellent option but a variety of other free flaps are now being utilized for ASB reconstruction.

The ALT is a great option for ASB and orbital reconstruction due to its versatility and reliability ${ }^{[6,31,38,39]}$. The vascular anatomy, based off the descending branch of the lateral circumflex femoral artery, can be variable but typically includes more than one perforating vessel, which is a particularly useful benefit of perforator flaps when distinct skin paddles are needed ${ }^{[9,10,30,31]}$. A portion of the vastus lateralis can also be harvested as a chimeric flap for extensive orbitomaxillary defects requiring extra coverage for critical neurovascular structures and exposed dura ${ }^{[38,40]}$. Additional advantages include minimal donor site morbidity and feasibility of the simultaneous two-team approach to help decrease operative time ${ }^{[0,31]}$. Amin et al. ${ }^{[41]}$ described their use of the ALT to reconstruct ASB defects in five cases and midface defects in seven cases. The major complication rate in this series, which also included lateral skull base and scalp reconstruction, was $22 \%{ }^{[41]}$. A potential disadvantage of the ALT is a shorter pedicle length in comparison to the rectus abdominis or radial forearm ${ }^{[4,42]}$.

The fasciocutaneous or osteocutaneous radial forearm free flap (RFFF) is another reliable flap for ASB defects $^{[2,4,7,17]}$. The main advantages for ASB reconstruction are its pliable nature and ability to allow flap folding and contouring of complex defects ${ }^{[0]}$. It also has substantial pedicle length (up to $15 \mathrm{~cm}$ ) based off the radial artery that can reach recipient vessels and reduce the need for interposition vein grafts $^{[17]}$. In a case series of 20 patients, Chepeha et al. ${ }^{[7]}$ demonstrated the role of the RFFF in reinforcing low-volume skull base defects among patients who had prior skull base surgery or radiation. The RFFF was utilized in 14 patients $(70 \%)$ not only to provide a layer of vascularized tissue between the sinonasal cavity and intracranial space but also for local reconstruction such as obliteration of orbital defects. An osseous component was harvested in six of these 14 patients to help reconstruct the frontal orbital bar and upper facial skeleton ${ }^{[7,12]}$. The lack of substantial muscle and fat can be a disadvantage when large tissue volume is needed. Potential donor site complications include poor wound healing, tendon exposure, and decreased wrist range of motion ${ }^{[15]}$.

Extensive orbitomaxillary pathology may result in large palatal or midface defects requiring bony reconstruction in addition to coverage of dura and significant soft tissue replacement to obliterate dead space. Osseous reconstruction is often required to provide structural competence for anterior maxillary projection and along the inferior orbital rim and/or orbital floor. The scapula has often been considered the technique of choice for reconstructing total maxillectomy defects ${ }^{[35,43]}$. Recent popularization of the thoracodorsal artery scapular tip flap, initially described by Chepeha et al. ${ }^{[44]}$, permits the harvest of the versatile scapular tip with a separate, flexible soft tissue component to recontour the complex craniofacial skeleton. This technique omits the need for two separate free flaps and provides a long vascular pedicle reducing the role for interposition vein grafts ${ }^{[44]}$. The ability to harvest a variety of flaps off the subscapular 
system is particularly advantageous and allows for both watertight closure of dura and reinforcement of the bony facial structure with orbitomaxillary defects ${ }^{[9,34]}$. The simultaneous two-team approach is also very feasible for this donor site, particularly when it is harvested from the anterior approach ${ }^{[34]}$. Shipchandler et al. ${ }^{[35]}$ described the use of a layered osteocutaneous fibula free flap to provide excellent long-term outcomes in total maxillectomy defects including those with OE. The layered fibula is particularly adept at reconstructing the inferior orbital rim and the malar eminence. The authors concluded that utilizing the bone depth along with a malleable skin paddle results in a donor flap that is flexible enough to manage contiguous orbitomaxillary defects ${ }^{[35]}$.

\section{Free flap selection}

Despite previously reported algorithms for skull base reconstruction management ${ }^{[2,15,45-48]}$, there is no clear consensus regarding free flap selection due to the heterogeneity and complexity of ASB defects. The ability to create an effective watertight closure and separate the intracranial contents from the sinonasal cavity, orbit, and external environment is the most critical determinant for flap selection. There are a variety of other factors including defect size, location, vascular pedicle length, patient co-morbidities, surgeon experience, and institutional preference that influence flap choice. The thin, pliable nature of the RFFF is often ideal for smaller, low volume skull base defects and especially for recalcitrant CSF leaks or in the salvage setting ${ }^{[2,7]}$. Based on a retrospective review of 45 free flaps for skull base reconstruction, Weber et al ${ }^{[2]}$ specifically defined small defects as $<40 \mathrm{~mL}$ in volume and primarily recommended the RFFF for such defects. For larger ASB defects with substantial volume requirements, the myocutaneous or myofascial rectus abdominis, ALT, and latissimus are all viable options. The need for adequate skin coverage or multiple skin paddles as well as associated donor site morbidities can also influence free flap selection. Osseous free tissue transfer should be considered for defects extending to the orbit, nasal bone, or other craniofacial buttresses ${ }^{[6,9]}$. The scapula, fibula, and osteocutaneous RFFF have all been utilized to reconstruct mid-face and associated skull base defects with various advantages and disadvantages ${ }^{[7,34,35,44]}$. Vargo et al. ${ }^{[12]}$ recommended the osteocutaneous RFFF for high and middle anterior cranial defects due to similar thickness of the radial and frontal bones. Middle defects in this series included the supraorbital bar, frontal sinus, and overlying glabellar soft tissue, while high defects included the squamous portion of the frontal bone and upper forehead soft tissue ${ }^{[12]}$. Of note, free flaps are often used in conjunction with regional flaps such as the pericranial flap, if available, to create a multilayered closure.

\section{ENDOSCOPIC ENDONASAL DEFECTS}

As endoscopic endonasal techniques for ASB pathologies advance, the variety of reconstructive options including free grafts, local/regional vascularized pedicle flaps, and free tissue transfers also continues to evolve [Table 2].

\section{Non-vascular grafts}

Free grafts used in a multilayer fashion can be a simple but a highly effective method to reconstruct small ASB defects ${ }^{[8]}$. These are comprised of both autologous tissue grafts and non-autologous manufactured materials. Common autologous grafts include middle turbinate mucosal grafts, abdominal fat, fascia lata, and temporalis fascia ${ }^{[4,8,14]}$. Synthetic, non-cellular grafts (i.e., alloplastic and allogenic implants) include collagen matrix, acellular dermis, biological glues, and hydroxyapatite cements ${ }^{[4,6,8]}$. These non-vascular grafts are most successful among small defects with low-flow CSF leaks, exposed bony edges, and a wellvascularized tissue bed ${ }^{[8,14,49,50]}$.

\section{Locoregional grafts}

The majority of small endoscopic skull base defects can be reconstructed successfully with free tissue grafts, locoregional flaps, or a combination ${ }^{[14]}$. The posterior pedicled nasoseptal, or the Hadad-Bassagaisteguy flap, 
Table 2. Reconstructive options for endoscopic anterior skull base defects

\begin{tabular}{|c|c|c|c|c|c|}
\hline $\begin{array}{l}\text { Reconstructive } \\
\text { method }\end{array}$ & Clinical indications & Donor sites & Advantages & Disadvantages & Endoscopic considerations \\
\hline \multicolumn{6}{|l|}{ Non-vascular grafts } \\
\hline Mucosal & $\begin{array}{l}\text { Small volume defects, } \\
\text { minimal CSF leak risk }\end{array}$ & $\begin{array}{l}\text { Middle and inferior turbinate, } \\
\text { nasal septum/floor }\end{array}$ & -Minimal donor site morbidity & -Nasal crusting & \multirow{4}{*}{$\begin{array}{l}\text {-Multiple grafts often used in combination for } \\
\text { multilayer closure } \\
\text {-Optimal outcomes with well-vascularized wound } \\
\text { bed and exposed bony edges }\end{array}$} \\
\hline Fascia & $\begin{array}{l}\text { Small volume defects, } \\
\text { minimal CSF leak risk }\end{array}$ & Temporalis fascia, fascia lata & -Thin pliable tissue & -Additional incision required & \\
\hline Allografts & $\begin{array}{l}\text { Small volume defects, } \\
\text { minimal CSF leak risk }\end{array}$ & $\begin{array}{l}\text { DuraGen, AlloDerm, } \\
\text { DuraSeal, hydroxyapatite } \\
\text { elements }\end{array}$ & -No donor site morbidity & -Cost & \\
\hline Fat & $\begin{array}{l}\text { Small to large volume } \\
\text { defects }\end{array}$ & Abdomen, upper thigh & $\begin{array}{l}\text {-Obliterates dead space } \\
\text {-Large volume can be harvested }\end{array}$ & $\begin{array}{l}\text {-Additional incision required } \\
\text {-Atrophy }\end{array}$ & \\
\hline Reconstructive method & Clinical indications & Vascular supply & Advantages & Disadvantages & Endoscopic considerations \\
\hline \multicolumn{6}{|l|}{ Locoregional flaps ${ }^{\star}$} \\
\hline $\begin{array}{l}\text { Posterior pedicled } \\
\text { nasoseptal }\end{array}$ & $\begin{array}{l}\text { Moderate to large SB } \\
\text { defects, high-pressure CSF } \\
\text { leak }\end{array}$ & Posterior nasoseptal a. & $\begin{array}{l}\text {-Reliable vascularity } \\
\text {-Minimal donor site morbidity } \\
\text {-Low post-operative CSF leak } \\
\text { rates }\end{array}$ & $\begin{array}{l}\text {-Nasal crusting/obstruction } \\
\text {-Olfactory changes }\end{array}$ & $\begin{array}{l}\text {-Prior nasal surgery or septal resection may } \\
\text { compromise pedicle } \\
\text {-Potential limitations for very anterior or clival } \\
\text { defects }\end{array}$ \\
\hline $\begin{array}{l}\text { Posterior pedicled } \\
\text { inferior turbinate }\end{array}$ & Moderate SB defects & $\begin{array}{l}\text { Posterior lateral nasal septal } \\
\text { a. }\end{array}$ & $\begin{array}{l}\text {-Reliable option if posterior } \\
\text { nasoseptal a. previously } \\
\text { sacrificed } \\
\text {-Ability to cover large surface } \\
\text { area }\end{array}$ & $\begin{array}{l}\text {-Nasal crusting/obstruction } \\
\text {-Atrophic rhinitis }\end{array}$ & \\
\hline Paramedian forehead & Moderate SB defects & Supratrochlear a. & $\begin{array}{l}\text {-Viable option in previously } \\
\text { failed locoregional flaps } \\
\text {-Good pedicle mobility and } \\
\text { optimal location }\end{array}$ & -Forehead scar & $\begin{array}{l}\text {-Flap tunneled and rotated entry hole via exposed } \\
\text { nasion }{ }^{[57]}\end{array}$ \\
\hline Temporoparietal fascia & Large SB defects & Superficial temporal a. & $\begin{array}{l}\text {-Long vascular pedicle } \\
\text {-Reliable vascularity especially } \\
\text { in previously irradiated field }\end{array}$ & $\begin{array}{l}\text {-Limitations with flap transposition for } \\
\text { midline ASB defect } \\
\text {-Alopecia }\end{array}$ & $\begin{array}{l}\text {-Transposed through temporal-parietal tunnel and } \\
\text { via endoscopic transpterygoid approach }{ }^{[55]}\end{array}$ \\
\hline Pericranial & Large SB defects & $\begin{array}{l}\text { Supraorbital and } \\
\text { supratrochlear a. }\end{array}$ & $\begin{array}{l}\text {-Thin, malleable flap } \\
\text {-Reliable vascularity especially } \\
\text { in previously irradiated patients } \\
\text {-Extensive surface area }\end{array}$ & $\begin{array}{l}\text {-Lacks tissue volume and skin } \\
\text { component } \\
\text {-Alopecia }\end{array}$ & $\begin{array}{l}\text {-Endoscopic harvest and then transposed via } \\
\text { nasionectomy }\end{array}$ \\
\hline \multicolumn{6}{|l|}{ Free flaps } \\
\hline Radial forearm & $\begin{array}{l}\text { Small volume defects, } \\
\text { salvage cases }\end{array}$ & Radial a. & $\begin{array}{l}\text {-Thin, pliable adipofascial flap } \\
\text {-Long pedicle length }\end{array}$ & $\begin{array}{l}\text {-Lack of substantial muscle and fat } \\
\text {-Donor site morbidity (tendon exposure, } \\
\text { decreased wrist range of motion) }\end{array}$ & $\begin{array}{l}\text {-Anterior maxillotomy/transbuccal approach } \\
\text {-Retropharyngeal approach }\end{array}$ \\
\hline Serratus anterior & $\begin{array}{l}\text { Small volume defects, } \\
\text { salvage cases }\end{array}$ & Thoracodorsal a. & $\begin{array}{l}\text {-Long pedicle length } \\
\text {-Thin and malleable }\end{array}$ & $\begin{array}{l}\text {-Donor site morbidity (scapular } \\
\text { winging) }\end{array}$ & $\begin{array}{l}\text {-Transcervical and transnasal approach with novel } \\
\text { use of laparoscopic coil sutures for inset }{ }^{[61]}\end{array}$ \\
\hline
\end{tabular}


- Can be harvested with other flaps off subscapular system $\begin{array}{lll}\begin{array}{ll}\text { Larger volume defects, } \\ \text { salvage cases }\end{array} & \begin{array}{l}\text { Descending branch of lateral } \\ \text { femoral circumflex a. }\end{array} & \text {-Long, narrow, and flexible } \\ & & \text {-Substantial pedicle length }\end{array}$

-Temporary nasal obstruction

Endoscopic inset via sublabial approach through anterior maxillotomy

*Multiple other locoregional flaps including the bilateral nasoseptal flap, reverse nasoseptal flap, nasal floor flap, pedicled buccal fat pad flap, and palatal flap have also been described. SB: Skull base; CSF: cerebrospinal fluid; a: artery.

is considered to be the workhorse flap for endoscopic skull base defects and has helped revolutionize the field ${ }^{[4,14]}$. It is based on the posterior septal branch of the sphenopalatine artery and is composed of mucoperiosteum and mucoperichondrium. Large skull base defects extending from the frontal sinuses to the planum sphenoidale and between the orbital walls and even posterior fossa/clival defects can be repaired with this flap. The posterior pedicled nasoseptal flap is also associated with minimal morbidity and low rates of CSF leaks $(<5 \%)$ compared to free grafts ${ }^{[6,14,51,52]}$. A limitation of this reliable flap is that it often cannot be used when the nasal septum requires resection for oncologic margins. The posterior pedicled inferior turbinate flap is another intranasal flap that is typically reserved for posterior (i.e., sella and parasellar region) and midclival defects. It derives its blood supply from the inferior turbinate artery, which is a terminal branch of the posterior lateral nasal artery ${ }^{[53]}$. A variety of other local flaps have also been described in the literature including the bilateral nasoseptal flap, middle turbinate flap, and lateral nasal wall flaps ${ }^{[14]}$. Post-operative complications associated with these flaps can include nasal crusting/discharge, atrophic rhinitis, and olfactory changes but nasal life quality scores are usually not significantly impacted with these endoscopic techniques ${ }^{[4]}$.

Regional flaps (i.e., pericranial and temporoparietal fascia) are also vital for endoscopic ASB defects especially if endonasal options have been compromised by oncologic margins (i.e., sacrifice of the sphenopalatine artery) or for larger, complex defects ${ }^{[8]}$. The pliable nature of these flaps allows for safe and feasible tunneling into the sinonasal cavity. Fortes et al. ${ }^{[54]}$ developed a technique to transpose the temporoparietal fascial flap through a temporal-infratemporal tunnel and then into the sinonasal cavity via an endoscopic endonasal transpterygoid approach. Zanation et al. ${ }^{[5]}$ described a novel endoscopic harvest of the pericranial flap compared to the traditional coronal approach, which can then be transposed through a small nasionectomy into the sinonasal cavity. A novel endoscopic-assisted paramedian forehead flap used to repair an ASB defect with a recalcitrant CSF leak has also been reported ${ }^{[5]}$. The paramedian forehead flap is noted to have good pedicle mobility and minimal donor site morbidity ${ }^{[56]}$.

Harvey et al ${ }^{[52]}$ demonstrated a lower post-operative CSF leak rate for vascularized reconstruction of endoscopic skull base defects (6.7\%) compared to that associated with non-vascular graft reconstruction (15.6\%). Thus, locoregional pedicled flaps often used in combination with non-vascular free grafts have become the mainstay for ASB defects following endoscopic endonasal resection due to reduced postoperative CSF leaks ${ }^{[6,8]}$.

\section{Free microvascular tissue transfers}

Free microvascular transfer typically is required only after locoregional flap options have been exhausted, or in previously irradiated patients where vascularized tissue provides critical coverage of the dura and/or carotid artery. As previously discussed, the rectus abdominus, ALT, and RFFF are commonly 
used to reconstruct open ASB defects due to their versatility, long vascular pedicles, and adequate skin paddles $^{[5,8,14]}$. However, there are a multitude of challenges to consider with free tissue transfer via an endoscopic approach. These include access to the defect, narrow constraints of the sinonasal cavity, recipient vessels for microvascular anastomosis, and inset ${ }^{[57]}$. Thus, a disadvantage of some traditional flaps is excessive bulk resulting in difficult tunneling and/or flap inset.

The first description of free microvascular transfer for endoscopic skull base reconstruction used the vastus lateralis donor site for cribiform and planum sphenoidale defects in a salvage setting ${ }^{[5]}$. This technique utilizes an endoscopic inset by placing the flap into the sinonasal cavity via a sublabial approach through an anterior maxillotomy to access an ASB defect in order to prevent a craniotomy. Endoscopic medial maxillectomy is also required to place the flap against the skull base. The narrow and flexible strip of vastus lateralis is an ideal free flap as it can be packed and conformed within the sinonasal cavity. The substantial length that can be harvested with the vastus lateralis flap (up to $26 \mathrm{~cm}$ ) in addition to a long pedicle length $(8 \mathrm{~cm})$ is a significant advantage of this flap. No vein grafts were needed in this case series. The long pedicle based off the descending branch of the lateral femoral circumflex artery also helps to ensure excellent pedicle geometry and a tension-free anastomosis after it is tunneled through the buccal space, deep to the buccinator, to reach the recipient facial vessels. The authors highlight the importance of meticulous flap inset and placement only after all the sinonasal mucosa along the skull base and medial orbital walls has been debrided. This helps the muscle flap adhere to the skull base surfaces and completely obliterate the space between the sinonasal and intracranial cavities. The flap is then bolstered in place with a combination of absorbable and non-absorbable nasal packing subsequently followed by nasal trumpets. The exposed muscle bulk will gradually atrophy and rapidly remucosalize within the sinonasal cavity. The main disadvantage of this technique is near total nasal obstruction in the immediate postoperative period ${ }^{[5]}$.

In a recent case series, Pipkorn et al. ${ }^{[58]}$ described the use of a RFFF via a similar transbuccal-anterior antrostomy approach for skull base reconstruction after endoscopic endonasal surgery. The authors advocate for the use of an adipofascial flap without a skin paddle, wide transmaxillary exposure for safe delivery of the flap, and precise defect measurement prior to harvest due to frequent overestimation with endoscopic views ${ }^{[58]}$. Rodriguez-Lorenzo et al..$^{[59]}$ used a similar transmaxillary approach for endoscopic inset of both muscle (i.e., vastus) and adipofascial flaps (i.e., ALT and RFFF) for complex ASB reconstructions in a small case series.

Krane et al ${ }^{[60]}$ described a novel surgical technique utilizing a laparoscopic fixation device to assist with free tissue transfer inset for a complex skull base defect in the setting of chronic clival and cervical spine osteomyelitis. Using a combined transcervical and transnasal endoscopic approach, the pedicle of an anterior serratus free tissue transfer was tunneled from the posterior nasopharynx to the neck. Due to concerns for free flap prolapse and ineffective endoscopic suturing in the setting of osteomyelitis, laparoscopic coil sutures were used to circumferentially secure the muscular free flap to the surrounding mucosa under endoscopic visualization. The soft palate was also sutured to the lateral and posterior pharyngeal walls to help suspend the inferior aspect of the flap ${ }^{[60]}$.

A case report by London et al. ${ }^{[6]]}$ described a retropharyngeal approach for tunneling a RFFF to repair a clival defect in the setting of osteoradionecrosis. Vieira et al. ${ }^{[62]}$ also reported a case in which a vastus lateralis free flap was utilized for clival reconstruction due to osteoradionecrosis secondary to proton beam therapy. Another approach using the transmaxillary corridor to tunnel the pedicle across the face in the maxillary subcutaneous tissue for contralateral facial vessel anastomosis has also been described ${ }^{[63]}$. 


\section{OTHER CONSIDERATIONS}

\section{Complications}

Post-operative complications can be a significant challenge among this patient cohort due to the complex anatomy, prior surgery, irradiated tissue, and other medical co-morbidities ${ }^{[5,7,9]}$. CSF leak is the most common complication after reconstructive skull base surgery but other complications, such as meningitis, pneumocephalus, wound dehiscence, and stroke, can also occur ${ }^{[7,31]}$. In a large retrospective comparison study, Neligan et al..$^{[22]}$ demonstrated that the overall complication rate was $33.5 \%$ in free flaps, $38.8 \%$ in local flaps, and $75 \%$ in pedicled flaps. The authors also reported compromised wound healing in $36.3 \%$ of pedicled flaps compared to only $10 \%$ of free flaps ${ }^{[22]}$. The rotational limitations and gravitation pull associated with regional flaps are hypothesized to contribute to increased rates of wound dehiscence ${ }^{[0]}$. Additionally, the distal portion of regional pedicled flaps is often the most vital aspect for effective reconstruction but can also be the most at risk with poor flap circulation ${ }^{[30]}$. In a different retrospective series of cranial base reconstructions, Chang et al. ${ }^{[21]}$ reported an overall complication rate of $29 \%$ with the temporalis muscle flap and $31 \%$ with free tissue transfer. Llorente et al.$^{[15]}$ reported an overall complication rate of $17 \%$ and a free flap success rate of $94 \%$ among 62 flaps used for skull base defects. The majority of these defects involved the ASB (81\%) and reconstruction was primarily performed with an ALT (37\%). Chepeha et al. ${ }^{[7]}$ also demonstrated that a RFFF in conjunction with the pericranial flap can result in a low rate of major post-operative complications (15\%) in salvage skull base surgery. It is important to recognize limitations associated with highlighted retrospective studies including the inherent selection bias and heterogeneity regarding methods of reconstruction, complications reported, and various patient comorbidities.

\section{Recipient vessels}

The choice of recipient vessels is an integral aspect of successful free flap outcomes for both open and endoscopic reconstruction ${ }^{[15]}$. The ipsilateral facial vessels are used most frequently if they are available because they can be traced to level of the mandible and have an accompanying vein. In a retrospective review of 11 free flaps, Vargo et al. ${ }^{[12]}$ exclusively used the superficial temporal vessels for microvascular anastomosis. While the artery is typically acceptable for anastomosis, the size of the vein can be variable. Superior thyroid, lingual, and occipital arteries can also be utilized ${ }^{[45]}$. Typical recipient vessels may not be viable options in salvage cases, patients with recent infection, or in a vessel-depleted neck, in which use of the transverse cervical artery is often required. The dorsal scapular artery has also been described as a viable recipient vessel during free flap reconstruction in a vessel-depleted neck ${ }^{[64]}$. Interposition vein grafts may be required to lengthen the venous and/or arterial pedicle despite appropriate pre-operative planning and intra-operative efforts with overall success rates around $85 \%{ }^{[65]}$. Different vein grafts have been described in the literature, such as the external jugular, facial, and cephalic, but the saphenous vein is most commonly used.

Based on a recent retrospective cohort study of 31 patients, Hanick et al. ${ }^{[66]}$ reported the use of the angular vessels as a viable option for microvascular anastomosis in head and neck reconstruction. Despite smallercaliber vessels, the angular artery and vein can be advantageous for ASB defects due to their proximity to the sinonasal cavity and shorter pedicle requirements. This vascular supply can also be beneficial in the setting of previously failed reconstructions or irradiation to the neck ${ }^{[6]}$. Other potential recipient vessels that have been described based on cadaveric studies include the superior trochlear system ${ }^{[23]}$. and the third segment of the maxillary artery ${ }^{[67]}$. Reyes et al. ${ }^{[23]}$ reported an average diameter of $2.5 \mathrm{~mm}^{2}$ for the superior trochlear artery in six cadavers, which was then anastomosed to a fascia lata free flap for ASB reconstruction. The superior trochlear vessels were isolated via a Lynch incision and the fascia lata pedicle was then tunneled through a radix osteotomy ${ }^{[23]}$. This novel technique could be a feasible option for complex skull base defects especially in salvage cases but further in vivo studies are warranted. 


\section{CONCLUSION}

Craniofacial and ASB reconstruction can be challenging due to complex anatomy and associated postoperative complications. A variety of reconstructive techniques have been described for both open and endoscopic approaches, and it is important to be familiar with these options to optimize surgical outcomes. Free tissue transfer is a viable option for extensive ASB defects especially in the salvage setting. The primary goal is to create a watertight closure and the optimal choice depends on location of the defect, size, prior surgery/radiation, medical comorbidities, and surgeon experience. As open and endoscopic skull base surgeries continue to advance, innovative techniques to reconstruct these challenging defects will also continue to evolve including free tissue transfer.

\section{DECLARATIONS}

\section{Authors' contributions}

Conceived and designed the article's objective: Naik AN, Parikh AS, Kang SY

Performed the literature review and drafted of the article: Naik AN, Lancione PJ

All authors were involved in interpretation of the data, provided critical revisions, and approved this version to be published.

\section{Availability of data and materials}

Not applicable.

\section{Financial support and sponsorship}

None.

\section{Conflicts of interest}

All authors declared that there are no conflicts of interest.

\section{Ethical approval and consent to participate}

Not applicable.

\section{Consent for publication}

Not applicable.

\section{Copyright}

(c) The Author(s) 2021.

\section{REFERENCES}

1. Moyer JS, Chepeha DB, Teknos TN. Contemporary skull base reconstruction. Curr Opin Otolaryngol Head Neck Surg 2004;12:2949. DOI PubMed

2. Weber SM, Kim JH, Wax MK. Role of free tissue transfer in skull base reconstruction. Otolaryngol Head Neck Surg 2007;136:914-9. DOI PubMed

3. Teknos TN, Smith JC, Day TA, Netterville JL, Burkey BB. Microvascular free tissue transfer in reconstructing skull base defects: lessons learned. Laryngoscope 2002;112:1871-6. DOI PubMed

4. Reyes C, Mason E, Solares CA. Panorama of reconstruction of skull base defects: from traditional open to endonasal endoscopic approaches, from free grafts to microvascular flaps. Int Arch Otorhinolaryngol 2014;18:S179-86. DOI PubMed PMC

5. Kang SY, Eskander A, Hachem RA, et al. Salvage skull base reconstruction in the endoscopic era: Vastus lateralis free tissue transfer. Head Neck 2018;40:E45-52. DOI PubMed

6. Kwon D, Iloreta A, Miles B, Inman J. Open anterior skull base reconstruction: a contemporary review. Semin Plast Surg 2017;31:18996. DOI PubMed PMC

7. Chepeha DB, Wang SJ, Marentette LJ, Thompson BG, Prince ME, Teknos TN. Radial forearm free tissue transfer reduces complications in salvage skull base surgery. Otolaryngol Head Neck Surg 2004;131:958-63. DOI PubMed

8. Ein L, Sargi Z, Nicolli EA. Update on anterior skull base reconstruction. Curr Opin Otolaryngol Head Neck Surg 2019;27:426-30. DOI PubMed 
9. Wang W, Vincent A, Sokoya M, Kohlert S, Kadakia S, Ducic Y. Free-flap reconstruction of skull base and orbital defects. Semin Plast Surg 2019;33:72-7. DOI PubMed PMC

10. Chapchay K, Weinberger J, Eliashar R, Adler N. Anterior skull base reconstruction following ablative surgery for osteoradionecrosis: case report and review of literature. Ann Otol Rhinol Laryngol 2019;128:1134-40. DOI PubMed

11. Bell EB, Cohen ER, Sargi Z, Leibowitz J. Free tissue reconstruction of the anterior skull base: a review. World J Otorhinolaryngol Head Neck Surg 2020;6:132-6. DOI PubMed PMC

12. Vargo JD, Przylecki W, Camarata PJ, Andrews BT. Classification and microvascular flap selection for anterior cranial fossa reconstruction. J Reconstr Microsurg 2018;34:590-600. DOI PubMed

13. Lal D, Cain RB. Updates in reconstruction of skull base defects. Curr Opin Otolaryngol Head Neck Surg 2014;22:419-28. DOI PubMed

14. Hachem RA, Elkhatib A, Beer-Furlan A, Prevedello D, Carrau R. Reconstructive techniques in skull base surgery after resection of malignant lesions: a wide array of choices. Curr Opin Otolaryngol Head Neck Surg 2016;24:91-7. DOI PubMed

15. Llorente JL, Lopez F, Camporro D, et al. Outcomes following microvascular free tissue transfer in reconstructing skull base defects. $J$ Neurol Surg B Skull Base 2013;74:324-30. DOI PubMed PMC

16. Snyderman CH, Janecka IP, Sekhar LN, Sen CN, Eibling DE. Anterior cranial base reconstruction: role of galeal and pericranial flaps. Laryngoscope 1990;100:607-14. DOI PubMed

17. Yeo IS, Kim SH, Park MC, Lim H, Kim JH, Lee IJ. Successful reconstruction of irradiated anterior skull base defect using the dual flap technique involving local pericranial flap and radial forearm free flap. J Craniofac Surg 2014;25:1376-8. DOI PubMed

18. Califano J, Cordeiro PG, Disa JJ, et al. Anterior cranial base reconstruction using free tissue transfer: changing trends. Head Neck 2003;25:89-96. DOI PubMed

19. Chang BA, Ryan Hall S, Howard BE, et al. Submental flap for reconstruction of anterior skull base, orbital, and high facial defects. Am J Otolaryngol 2019;40:218-23. DOI PubMed

20. Ferrari M, Vural A, Schreiber A, et al. Side-door temporoparietal fascia flap: a novel strategy for anterior skull base reconstruction. World Neurosurg 2019;126:e360-70. DOI PubMed

21. Chang DW, Langstein HN, Gupta A, et al. Reconstructive management of cranial base defects after tumor ablation. Plast Reconstr Surg 2001;107:1346-55; discussion 1356. DOI PubMed

22. Neligan PC, Mulholland S, Irish J, et al. Flap selection in cranial base reconstruction. Plast Reconstr Surg 1996;98:1159-66; discussion 1167. DOI PubMed

23. Reyes C, Solares CA, Fritz MA, Groves M, Bentley H. Fascia lata free flap anastomosed to the superior trochlear system for reconstruction of the anterior skull base. J Neurol Surg B Skull Base 2017;78:393-8. DOI PubMed PMC

24. Badhey A, Haidar Y, Genden E. Soft tissue microvascular reconstruction of orbital exenteration defects. Semin Plast Surg 2019;33:125-31. DOI PubMed PMC

25. Chepeha DB, Wang SJ, Marentette LJ, et al. Restoration of the orbital aesthetic subunit in complex midface defects. Laryngoscope 2004;114:1706-13. DOI PubMed

26. Rabey N, Abood A, Gillespie P, Athanassoglou V, Rene C, Malata CM. Reconstruction of complex orbital exenteration defects: a single center's experience with a five-year follow-up. Ann Plast Surg 2014;73:158-63. DOI PubMed

27. Urken ML, Catalano PJ, Sen C, Post K, Futran N, Biller HF. Free tissue transfer for skull base reconstruction analysis of complications and a classification scheme for defining skull base defects. Arch Otolaryngol Head Neck Surg 1993;119:1318-25. DOI PubMed

28. Chiu ES, Kraus D, Bui DT, et al. Anterior and middle cranial fossa skull base reconstruction using microvascular free tissue techniques: surgical complications and functional outcomes. Ann Plast Surg 2008;60:514-20. DOI PubMed

29. Kang SY, Spector ME, Chepeha DB. Perforator based rectus free tissue transfer for head and neck reconstruction: New reconstructive advantages from an old friend. Oral Oncol 2017;74:163-70. DOI PubMed

30. Marchetti C, Gessaroli M, Cipriani R, Contedini F, Frattarelli M, Staffa G. Use of "perforator flaps" in skull base reconstruction after tumor resection. Plast Reconstr Surg 2002;110:1303-9. DOI PubMed

31. Hanasono MM, Sacks JM, Goel N, Ayad M, Skoracki RJ. The anterolateral thigh free flap for skull base reconstruction. Otolaryngol Head Neck Surg 2009;140:855-60. DOI PubMed

32. Iida $\mathrm{H}$. The advantage of the anterolateral thigh flap for reconstruction of the anterior skull base defect in recurrent cases. Plast Reconstr Surg 2003;112:703-4. DOI PubMed

33. Lo KC, Jeng CH, Lin HC, Hsieh CH, Chen CL. A free composite de-epithelialized anterolateral thigh and the vastus lateralis muscle flap for the reconstruction of a large defect of the anterior skull base: a case report. Microsurgery 2011;31:568-71. DOI PubMed

34. Paprottka FJ, Krezdorn N, Ipaktchi R, Radtke C, Vogt PM. Plastic reconstructive surgery techniques for defect coverage of extended skull base defects. J Plast Reconstr Aesthet Surg 2016;69:1266-74. DOI PubMed

35. Shipchandler TZ, Waters HH, Knott PD, Fritz MA. Orbitomaxillary reconstruction using the layered fibula osteocutaneous flap. Arch Facial Plast Surg 2012;14:110-5. DOI PubMed

36. Barrow DL, Nahai F, Tindall GT. The use of greater omentum vascularized free flaps for neurosurgical disorders requiring reconstruction. J Neurosurg 1984;60:305-11. DOI PubMed

37. Yamada A, Harii K, Ueda K, Asato H. Free rectus abdominis muscle reconstruction of the anterior skull base. Br J Plast Surg 1992;45:302-6. DOI PubMed

38. Ali RS, Bluebond-Langner R, Rodriguez ED, Cheng MH. The versatility of the anterolateral thigh flap. Plast Reconstr Surg 2009;124:e395-407. DOI PubMed

39. Malata CM, Tehrani H, Kumiponjera D, Hardy DG, Moffat DA. Use of anterolateral thigh and lateral arm fasciocutaneous free flaps in 
lateral skull base reconstruction. Ann Plast Surg 2006;57:169-75; discussion 176. DOI PubMed

40. Karonidis A, Ren Chang L. Using the distal part of vastus lateralis muscle as chimeric anterolateral thigh free flap is a more flexible tool for head and neck reconstruction. Eur J Plast Surg 2010;33:1-5.

41. Amin A, Rifaat M, Civantos F, Weed D, Abu-Sedira M, Bassiouny M. Free anterolateral thigh flap for reconstruction of major craniofacial defects. J Reconstr Microsurg 2006;22:97-104. DOI PubMed

42. Aksu AE, Uzun H, Bitik O, Tunçbilek G, Şafak T. Microvascular tissue transfers for midfacial and anterior cranial base reconstruction. J Craniofac Surg 2017;28:659-63. DOI PubMed

43. Bidros RS, Metzinger SE, Guerra AB. The thoracodorsal artery perforator-scapular osteocutaneous (TDAP-SOC) flap for reconstruction of palatal and maxillary defects. Ann Plast Surg 2005;54:59-65. DOI PubMed

44. Chepeha DB, Khariwala SS, Chanowski EJ, et al. Thoracodorsal artery scapular tip autogenous transplant: vascularized bone with a long pedicle and flexible soft tissue. Arch Otolaryngol Head Neck Surg 2010;136:958-64. DOI PubMed

45. Pusic AL, Chen CM, Patel S, Cordeiro PG, Shah JP. Microvascular reconstruction of the skull base: a clinical approach to surgical defect classification and flap selection. Skull Base 2007;17:5-15. DOI PubMed PMC

46. Yano T, Okazaki M, Tanaka K, et al. A new concept for classifying skull base defects for reconstructive surgery. J Neurol Surg B Skull Base 2012;73:125-31. DOI PubMed PMC

47. Hanasono MM, Silva A, Skoracki RJ, et al. Skull base reconstruction: an updated approach. Plast Reconstr Surg 2011;128:675-86. DOI PubMed

48. Yamamoto Y, Minakawa H, Kawashima K, et al. Experience with 24 cases of reconstructive anterior skull base surgery: classification and evaluation of postoperative facial appearance. Skull Base Surg 2000;10:65-70. DOI PubMed PMC

49. Turri-Zanoni M, Zocchi J, Lambertoni A, et al. Endoscopic endonasal reconstruction of anterior skull base defects: what factors really affect the outcomes? World Neurosurg 2018;116:e436-43. DOI PubMed

50. Ruggeri AG, Cappelletti M, Giovannetti F, Priore P, Pichierri A, Delfini R. Proposal of standardization of closure techniques after endoscopic pituitary and skull base surgery based on postoperative cerebrospinal fluid leak risk classification. J Craniofac Surg 2019;30:1027-32. DOI PubMed

51. Thorp BD, Sreenath SB, Ebert CS, Zanation AM. Endoscopic skull base reconstruction: a review and clinical case series of 152 vascularized flaps used for surgical skull base defects in the setting of intraoperative cerebrospinal fluid leak. Neurosurg Focus 2014;37:E4. DOI PubMed

52. Harvey RJ, Parmar P, Sacks R, Zanation AM. Endoscopic skull base reconstruction of large dural defects: a systematic review of published evidence. Laryngoscope 2012;122:452-9. DOI PubMed

53. Clavenna MJ, Turner JH, Chandra RK. Pedicled flaps in endoscopic skull base reconstruction: review of current techniques. Curr Opin Otolaryngol Head Neck Surg 2015;23:71-7. DOI PubMed

54. Fortes FS, Carrau RL, Snyderman CH, et al. Transpterygoid transposition of a temporoparietal fascia flap: a new method for skull base reconstruction after endoscopic expanded endonasal approaches. Laryngoscope 2007;117:970-6. DOI PubMed

55. Zanation AM, Snyderman CH, Carrau RL, Kassam AB, Gardner PA, Prevedello DM. Minimally invasive endoscopic pericranial flap: a new method for endonasal skull base reconstruction. Laryngoscope 2009;119:13-8. DOI PubMed

56. Bresler AY, Mir G, Grube J, et al. Endoscopic paramedian forehead flap reconstruction of the anterior skull base for recalcitrant cerebrospinal fluid leaks: minimally invasive adaptation of ancient flap. World Neurosurg 2019;130:37-41. DOI PubMed

57. Dang RP, Roland LT, Sharon JD, Doering M, Chicoine MR, Pipkorn P. Pedicle corridors and vessel options for free flap reconstruction following endoscopic endonasal skull base surgery: a systematic review. J Neurol Surg B 2019. DOI

58. Pipkorn P, Lee JJ, Zenga J, Chicoine MR. Endoscopic adipofascial radial forearm free flap reconstruction of the skull base: a technical update. J Neurol Surg B Skull Base 2020. DOI

59. Rodriguez-Lorenzo A, Driessen C, Mani M, Lidian A, Gudjonsson O, Stigare E. Endoscopic assisted insetting of free flaps in anterior skull base reconstruction: a preliminary report of five cases. Microsurgery 2020;40:460-7. DOI PubMed

60. Krane NA, Troob SH, Wax MK. Combined endoscopic and transcervical approach for free flap reconstruction of nasopharyngeal and clival defects: a case report. Microsurgery 2019;39:259-62. DOI PubMed

61. London NR Jr, Ishii M, Gallia G, Boahene KDO. Technique for reconstruction of large clival defects through an endoscopic-assisted tunneled retropharyngeal approach. Int Forum Allergy Rhinol 2018;8:1454-8. DOI PubMed

62. Vieira S, Nabil A, Maza G, et al. Salvage free tissue transfer for clival osteoradionecrosis after repeat proton beam therapy. World Neurosurg 2020;138:485-90. DOI PubMed

63. Kato H, Mizuta K, Yamada N, Ueda N, Ito Y. A new route for passing a free flap vascular pedicle using contralateral facial vessels as recipient vessels in skull base reconstruction. Plast Reconstr Surg 2012;130:212e-4e. DOI PubMed

64. Rosko AJ, Ryan JT, Wizauer EJ, et al. Dorsal scapular artery as a recipient vessel in the vessel-depleted neck during free tissue transfer in head and neck reconstruction. Head Neck 2017;39:E72-6. DOI PubMed

65. Seim NB, Old M, Petrisor D, et al. Head and neck free flap survival when requiring interposition vein grafting: A multi-instiutional review. Oral Oncol 2020;101:104482. DOI PubMed

66. Hanick A, Ciolek P, Fritz M. Angular vessels for free-tissue transfer in head and neck reconstruction: clinical outcomes. Laryngoscope 2020;130:2589-92. DOI PubMed

67. Assam JH, Quinn TH, Militsakh ON. The maxillary artery as a recipient vessel option for complex midface and anterior skull base microsurgical repair: a cadaveric study. Microsurgery 2017;37:611-7. DOI PubMed 